\title{
Symbolic Meaning of Tayub Art in Sobo Village, Geyer, Grobogan
}

\author{
Darmawan $^{1}$, Sumarlam², Budhi Setiawan ${ }^{3}$, and Kundharu Saddhono ${ }^{4}$ \\ \{paklongawan777@gmail.com ${ }^{1}$, sumarlamwd@gmail.com² ${ }^{2}$, buset.74@ gmail.com ${ }^{3}$, \\ kundharu.uns@gmail.com ${ }^{4}$ \} \\ 1,2,3,4 Magister of Javanese Language and Literature, Universitas Sebelas Maret Surakarta, \\ Indonesia
}

\begin{abstract}
Tayub is a folk art that is still enjoyed by the community in Grobogan Regency. This study was aimed to describe the meaning of the symbols found in the Tayub show. The research method used was a qualitative descriptive method which is conducted through interview, observation and documentation. Tayub Madyo Laras art upholds the value of politeness and beauty in every performance-impolite, rude, and erotic acts are not used. In addition, in this modernization era, Tayub Madyo Laras art still survives and is still popular. The result of this study shows that there are various symbolic foods which are displayed in the Tayub art performance, including ceremony offerings, gamelan music, costumes, dance, and saweran.
\end{abstract}

Keywords: symbolic meaning, art, tayub, village

\section{INTRODUCTION}

Art is one of the culture's elements that colors human life. Art is also a beautiful human work. In the Javanese people's life, there are various kinds of traditional arts that still survive along the development of the era, one of them is tayub art. Tayub is a typical traditional arts of the Javanese tribe, especially Central and East Java. Nayub comes from the word tayub, consisting of two words, they are mataya which means dance and guyub which means getting along together. It is estimated that there are changes from two words become one word, ma-taya and gu-yub become tayub. [1]. Tayub's oldest function is for fertility ceremonies. Tayub dance in the midst of society also carries a sacred duty, because it becomes the center of village cleaning ceremonies, rasulan (after harvest), ruwatan, nadaran etc. The Tayub dance is closely related to fertility which is symbolized by the relationship between men and women which is a symbol of hope for fertile plants). [2]

Tayub is a term used by Javanese in dance. This art is very popular among Javanese community because of its attractive, dynamic, aesthetic and expressive appearance. Tayub Dance is a dance that makes women as the dominant element. Symbols are an introduction to understanding objects. In Tayub art performance, there are various symbols displayed and the meanings in these symbols are interesting to be explored. [3]. Tayub Art is one of traditional performing arts' forms that grows and develops rapidly in Blora Regency. The Tayub 
performance that developed in Blora has a form that similar to the form of Tayub performances that developed in other regions, such as: Purwodadi, Rembang, Pati, and Sragen. Tayub developed in the Palace's environment and the community's environment. Tayub in the palace's enviroment is manifested in the form of institutionalization of Bedaya dance, while the rural community expressed it through the Tayub dance institution. The type of Bedaya dance which until now is still often performed in the palace's environment as a ceremony dance implies the existence of strength or magic for the prosperity and welfare of the king and his marriage. This is similar with Tayub which is held in a series of village cleaning activities in rural communities.[4]

Tayub is a folk art that grows and develops in Blora Regency. The Tayub show involved audiences, especially men, to participate as Tayub dancers' partner. Therefore, Tayub dance has an erotic nature that is colored with sensuality and sexuality which is called as symbol of Rohana's fertility[5]. Professor of Anthropology at the University of Indonesia, Koentjaraningrat, said that culture is a system of ideas, senses, actions and works produced by humans in social life. Humans are created by God with intelligences and characters to be able to give birth and create a work of the noble tradition. In essence, culture has values that are always inherited, interpreted and implemented along with the patterns of social change.

According to the theory of R.M. Soedarsono in Harmonia Journal, tayub has three main functions, they are: ceremonial means, entertainment and show. Tayub was performed in various community needs, especially as a ceremonial means, such as village cleaning, alms the earth, and weddings. Clifford Geerzt in the Religion of Java even notes that ledek is considered as a prostitute (but kledek teledhek is almost always a prostitute). Not much different from Raflles in his book, The History of Java, describes Tayub dancers getting a negative stigma, almost all of them can be invited to sleep by wealthy men. This adds the bad impression of one of Indonesia's traditional dances.

Nayub comes from the word tayub, consisting of two words, they are mataya which means dance and guyub which means getting along together. It is estimated that there are changes from two words become one word, ma-ta-ya and gu-yub to be tayub.[6]. According to the complete Javanese dictionary, tayub, tayuban means dancing with ronggeng for fun. Tayub-ed means invited to dance [7]. Spradley mentioned three basic aspects used to study culture: it is related to what is done by people, what is known by people, and what is used by people. The first aspect refers to the cultural behaviour or the act of doing arts. [8]

Development era demands that the form of Langen Tayub's presentation that is vulgar, erotic and impolite becomes the public's spotlight and needs to be concerned. It seems that the form of Langen Tayub's presentation of the old model also occurs in similar art. The show last for an overnight. In the old Langen Tayub model, the performance was carried out from 21.00 WIB to 04.00 WIB (before dawn). As a result of the all-night performance, those who are involved in the show are not able to do normal work the next day. Besides that, shows that last night can disrupt the surrounding environment, which is likely to be less or not like the performance of Langen Tayub.[9]

\section{METHODS}

This research is a qualitative research, a method used in the context of participant observation. The main data is the data obtained from the interviews' result with selected informants and interviewees. The complementary (secondary) data is the data obtained from written sources, direct observation and interviews. Interviews were conducted through a 
structure of questions that are not strict, open questions and increasingly focused so that the information obtained is more complete and deep.

The analysis was done through data processing and analysis, both in the form of written data and oral data. Data analysis was done inductively, that is an analytical method to get data from the facts in the field. The data which was collected successfully was organized according to the subject matter and sub-problem. To produce proven data, each source of data (from wherever it came) was selected by comparing one another, so the facts could be accounted for. Selection and results of data analysis are data that will be used to write the report of the research. This research used a qualitative descriptive approach. The type of this research is descriptive research. The validity checking of the data used an extension of participation, persistence or regularity of observation, and triangulation.

\section{RESULT AND DISCUSSION}

The results of this study are as follows: (1)The existence of Tayub art in Sobo Village, Geyer District, Grobogan Regency is a form of ancestral cultural inheritance that is well received by the local community. The tayub art named Setyo Pradonggo and the existence of tayub art raises public awareness to preserve the culture of the region. Tayub Madyo Laras art upholds the value of politeness and beauty in every performance-the impolite, rude, and erotic acts are not used. In addition, in this modernization era, Tayub Madyo Laras art still survives and is still popular. In the performing arts of tayub, there are various symbols displayed, including ceremony offerings, gamelan music, costumes, dance, and saweran.

Offerings Ceremony: The meaning of the ceremony before the Tayub Art performance is as a form of effort to avoid obstacles that can occur during the performance by giving offerings as a sense of recognition (ngajeni) to the existence of spirits that the community believes as the guardian of an area (danyang). The offerings that the people offer are not to ask or worship these spirits but to pay so that they do not disturb humans. Because it has been outlined if the Jinn and Satan were created by God to disturb humans. [10]. It has a material meaning to ask for safety and continuity, and social meaning to respect ancestral traditions. As a proof of gratitude to the Creator who has given pleasure (thanks to God for all of the pleasure).

Gamelan Music: The accompaniment used by Tayub is a set of Javanese gamelan with laras slendro and laras pelog. A complete set of Javanese gamelan consists of 17 types of instruments such as Bonang Barung, Bonang Penerus, Slenthen, Kendhang Jawa (Ciblon), Kendang Jaipong, Gender, Kethuk, Kenong, Saron Barung, Saron Penerus, Demung, Gong, Kempul, Ketipung, Gambang, drums and cymbals. Those tools are different from one another, but are mixed to produce a very beautiful rhythm [11]. It has a material meaning for the integration of the taste of waranggono dance for its beauty in appearance and social meaning, that is to maintain traditional Javanese music, so that it can still be enjoyed by the community, especially in Sobo Village, Geyer District, Grobogan Regency.

Costume: The use of fashion means to clarify the roles and characters that are presented in the Tayub show. Joged costumes use a modern kebaya covered with short sleeves equipped with a middle pleat jarik (wiron). The use of slepe or belts that are tied as a cover on the waist that has previously been tied sampur in the belly. The selected color of the dominant joged is reddish yellow because it matches the character of the lively Tayub dance. Besides spele, you should not miss Tayub's interesting property,that issampur (shawl). The color is free. Usually made from chiffon complete with monte or tassel to beautify the sampur [12]. It has a material meaning, that is as an attraction or beauty in the performance of tayub art and social meaning, 
which is a form of self-identity that influences its image in society. A person's self-esteem can be judged by how they dress (ajining dhiri gumantung ing lathi).

Dance Movement: Dancers, performers and pengrawit are in one level, there is no separation of Tayub's actors with the stage. They are on the floor with carpet or mats. Joged is the nickname of the dancer in the Tayub performance, in general, joged is a dancer who is considered to be the main actor in the Tayub show. Without the joged, Tayub will not liven up. A joged person must be able to perform Tayub show like singing and dancing, therefore,joged is considered as an attractive dance of the show, so that the audience are interested in participating in the Tayub performance by dancing together or Tayuban. So joged must look sumeh, flexible, beautiful and attractive [13]. It has material meaning, that is to show the skill of Waranggono in entertaining tayub art lovers and the social meaning, that is as the allure of waranggono to audience of tayub.

Saweran: Saweran for waranggana (dancer Langen Tayub) is given by means directly on stage or during the ndara-ndara phase. Often this opportunity is used by a naughty penayub to give saweran by laying a hand in a way between breasts. The audiences of the Tayub show are not limited to certain ages. A show will not run smoothly without an audience. The audience at the Tayub show are the people who came to watch Tayuban to the performance arena, the audience could also take part in this performance by taking ngibing or giving a saweran for the dancer (ledhek) [14]. It has a material meaning, that is to request the desired gendhing and social meaning, that is the form of gratitude for tayub lovers because they feel comforted by the appearance of waranggono.

Discussion: In each Chinese Lunar Celebration, Chinese families in Pasar Lama Market who still keep the ash table will provide offerings at the ash table as a form of respect and expression of gratitude to the ancestors. It is also a way to maintain their relationship with ancestors and Gods. Chinese new year cake used as a dish is a stacking Chinese new year cake by which the number of level must be odd number, i.e. 1,3,5,7,9 and 11.The number of level of Chinese new year cake at home must conform to the financial condition of the family that provides it. The more prosperous the family, the more the number of levels of Chinese New Year cakeput on the ash table of their house. The relief is also given to some families who are unable to provide Chinese New Year cakein which they usually will get Chinese New Year cake from their relatives or neighbors. The activity of giving offerings in the form of food is a symbolic way for all societies to show obedience to other powers and show status differences between the giver and recipient of the dish. It is an attempt to establish cooperation with something that they believed it has strength beyond their ability.[17]

India is well-known for its dance. That is one of the most inherent characteristics of the community that the people dominantly have Hindureligion. They have been taught how to dance properly and correctly since childhood. The Tamil language for the dance is "Balle". Movement is the main element in human beings and movement is the oldest tool in human life to express desires or express spontaneous reflection within the human soul. Movement that is created through natural means within themselves or their bodies main element is a set or arrangement of movement. Movement is a symbol of expression and expression of the dance itself [18].

Likewise the human body, Hindu spirituality is a breath that becomes a power of living, dancing is a part of the body with all of its features, and arranging the dance is a part of the human brain that becomes the command center. That activity is not just a profession, but also develops into a way of life that unites Truth, Purity, through Beauty.

The development of the fashion area remainscarries the progress so thay it produces various trends and styles. This does not get rid of the advances in technology and media so 
that the various modes and styles of clothing continue to develop. Clothing is also a social symbol that gives a cultural identity to someone. Fashion can be seen from various perspectives, one of them is religious perspective. For example, in the United States, fashion does not have such a deep meaning as in Java. They consider fashion merely as a picture of fashion trends that are glamorous, magnificent and do not deprive of a graceful side for the wearer. This surely has an influence on who does not understand the trend and who has the ability to purchase.

In Pakistan, if a qorirecites the Quran well with the tunable voicethen he will be giventhe money. According to the experience of people who have experienced it, "Giving the money is the customs of the Pakistani in glorifying the qori there; moreover, we can beautify it they serve us like kings as we can beautify the quran..Allah glorifies us with the Al Qur'an.

Some of the features of the Javanese gamelan (traditional music instruments) are in the audio and visual aspects. The features in audio aspects include: tone color, scale system, interval, and sound wave, while the features of the visual aspects include: shape, construction, beauty of the material used, and ornaments. Features in both aspects and quality support in its musical aspects encourage the world to recognize that Javanese gamelan is 'the most sophisticated music in the world'. Countries that have advanced and have the opportunity to learn world music, for example, United States, Canada, Japan, Europe, Australia, and several other countries have made Javanese gamelan as a symbol of status at several universities. This is surely very different from the meaning contained in Javanese philosophy [21].

\section{CONCLUSION}

The development of Tayub traditional arts in Grobogan Regency, especially in Sobo Village, should be highlighted by the sGrobogan Regional Government (Tourism and Culture Service), besides to maintain its existence, it can be one of the assets owned by Grobogan Regency and a form of cultural preservation. The Sobo Village community is expected to continue to preserve the traditional Madyo Laras art in order to survive and be popular in the modern era as it is today. So that tayub traditional art will still be inherited to the next generation. Because everything related to the performance of the Tayub Art (tledhek) has a high philosophical value based on the symbolic meaning described in this study.

\section{REFERENCE}

[1] Ben Suharto. Tayub (Pertunjukan dan Ritus Kesuburan). Bandung: Masyarakat Seni Pertunjukan ndonesia. Arti. Line.1999.

[2] Noordiana., Juwariyah, A. \& Inda, F. The Impact of Tayub Exploitation on The Tradition and Life of Javanese Society. Harmonia: Journal of Arts Research and Education, 16(2), 133-142. 2016

[3] Pigeaud. Kerajaan-Kerajaan Islam di Jawa (Peralihan dari Majapahit ke Mataram). Terj. Gratifitipers dan KITLV Kejayaan kerajaan Demak pada dasawarsa terakhir abad ke-15 dan paro pertama abad ke-16. 1985

[4] Darmasti. "TARI SESAJI PANGENTAS BILAHI SUDRA TINGAL." Harmonia: Journal of Arts Research and Education [Online], 12.2 (2012): n. pag. Web. 24 Sep. 2017

[5] HARMONIA : Journal of Arts Research and Education 14 (1) : 65-71. 2014

[6] Rohana. Penari perempuan dalam Tayub di Blora Jawa Tengah: Sebuah Pendekatan Etnokoreografi. Surakarta: ISI Press Surakarta. 2007

[7] Ben Suharto. Tayub (Pertunjukan dan Ritus Kesuburan). Bandung: Masyarakat Seni Pertunjukan ndonesia. Arti. Line. 1999. 
[8] Mangunsuwito, S.A. Kamus Bahasa Jawa (Jawa-Indonesia). Bandung : Yrama Widya. 2002

[9] Juwariyah, A. ''Langen Tayub Padang Bulan" As A Manifestation of Social and Cultural Change in Community. Harmonia: Journal of Arts Research And Education, 18(2), 191-199. 2018

[10] Marhaendra Putra Hutama marhendraph. @gmail.com Sri Utami sri.utami.mpd@unitomo.ac.id Universitas Dr. Soetomo Surabaya. Jurnal Ilmiah : FONEMA, Vol 1, Nomor 1, Halaman 74-87.2018

[11] A. Jocuns. Communicative of practices in American Gamelan Orchestra. Mediator.Vol 4. No.2. 2003

[12] Ayoeningsih Dyah Jurusan Seni Rupa, Sekolah Tinggi Seni Indonesia-Bandung. Makna Simbolis pada Unsur Visual Kostum Tari Topeng Babakan Cirebon Keni Arja di Desa Slangit. ITB J. Vis. Art. Vol. 1 D, No. 2, 224-245. 2007

[13] Suharji. Bedhaya Bedhah Madiun dance: As a tourism superior asset in puro Mangkunagaran. Harmonia: Journal of Arts Research and Education 17 (2), 190-198. 2017

[14] Budy, E. The symbolical meaning of Macanan dance in Barongan Blora. Harmonia: Journal of Arts Research And Education, 17(2), 129-135. 2017

[15] Y. Kusmayadi .Program Studi Pendidikan Sejarah, FKIP, Universitas Galuh Ciamis. Tradisi Sawer Penganten Sunda Di Desa Parigi Kecamatan Parigi Kabupaten Pangandaran .Jurnal Agastya. Vol. 8 No. 2 juli 2018

[16] Juwariyah, A. ' 'Langen Tayub Padang Bulan" As A Manifestation of Social and Cultural Change in Community. Harmonia: Journal of Arts Research And Education, 18(2), 191 199. 2018

[17] Dice, Elizabeth A. Western and Chinese New Year's celebrations / Elizabeth A. Dice. New York: Chelsea House. 2009

[18] Rama, Swami. Interpretation of Ahmad Kahfi. Spirituality Transforms With and Outside of One 'Self. Surabaya: Paramita, 2011

[19] Barnard, Malcolm. Fashion as Communication: Ways to Communicate Identity, Social, Sexual, Class, and Gender:. Yogyakarta: Jalasutra. 2011

[20] Vetter, Roger. "More Than Meets The Eye and Ear: Gamelan and Their Meaning in A Central Javanese Palace", dalam Journal of the Society for Asian Music. Vol. XXXII2. University of Hawaii. 2001

[21] K. Saddhono, S. T, Widodo, M. T. Al Makmun, and M. Tozu, "The study of philosophical meaning of batik and kimono motifs to foster collaborative creative industry." Asian Soc. Sci. vol. 10 no. 9 pp 52-61, 2014 
